\title{
ICT Collaboration Tools for Virtual Teams in Terms of the SECI Model
}

\author{
https://doi.org/10.3991/ijep.v7i1.6502 \\ Monika Dávideková \\ Faculty of Management, Comenius University, Bratislava, Slovakia \\ monika.davidekova@fm. uniba.sk \\ Jozef Hvorecký \\ Vysoká škola manažmentu (School of Management), Bratislava, Slovakia \\ jhvorecky@vsm.sk
}

\begin{abstract}
Nowadays the current state of development of information and communication technology (ICT) connects individuals across time and space in one common environment that is accessible for anyone, creating the virtual world. To collaborate with somebody or to participate in a team activity does not require a physical presence anymore. Virtual settings allow real-time communication and cooperation across any distance at any time with negligible delay. ICT allows formation of virtual teams to accomplish various functions in work, education and private life. Compared to local teams of physically present individuals, the collaboration in virtual environments is more intensively influenced by external and internal impact factors and requires active motivation of the team members, extensive support by their team leader and appropriate technology. Among all the available ICT tools, not each ICT tool is equally suitable for each and every team activity. This paper aims to provide analysis of various ICT tools, to disclose their potential to contribute to team's quality communication and to reduce drawbacks caused by impersonal environment. Our aim is to optimize the composition of the ICT supporting infrastructure in order to form successful and effective collaboration.
\end{abstract}

Keywords—-knowledge management, collaboration, virtual teams, ICT, SECI model

\section{Introduction}

In today's Digital Era, digital environments allow real-time communication and collaboration across any distance. The rise of digital technology, especially the development of affordable mobile and wireless applied engineering science, the dominant technology driver [[1]], enabled the emergence of information and communication technology (ICT) that is available to everyone and everywhere around the globe and allows interconnecting individuals. ICT enables the formation and sharing of information and knowledge at long distances in much greater extent than was possible at any time before. The affordability and availability of ICT has spread it among people 
at a great pace making it ubiquitous. The mobile cellular technology achieved in only five years the same level of distribution as land-lines have achieved in thirty-one years [[2]]. Through the omnipresence of ICT, the share of information among individuals is within seconds today.

ICT maintains the sense of presence and awareness of remote locations [[3]] and formatting of dispersed collaborative teams. The members of distributed teams can exchange their needed information in a timely manner and replace their physical "space of place" with the electronic "space of flows" [[4]]. This technology-enhanced change leads to a wide application of virtual presence in diverse activities: work, education, government and personal life. It has become an integral part of our lives [[5]] and represents a substantial portion of our daily habits today. For those, who adopted this style of collaboration, it changed our daily routine in every side of lives [[6]].

Besides overcoming spatial distances, ICT also raised the amount of storable knowledge into very large data volumes, notably cut down the execution times of task conducting, extended the space for collaboration and excessively increased the rate of informational exchange around the globe [[7]]. Through the use of ICTs, the knowledge and expertise acquired during millennia became instantly globally accessible to broad public, to each one individual on the planet [[8]].

The usage of adequate and satisfactory applications has made virtual communication a central segment of everyday life in companies and organizations [[9]]. Nowadays, the information and communication technology is perceived to represent the driver of long-run economic growth [[1]] through its cost effectiveness and disposal of powerful tools fostering the inter- and intra-enterprise collaboration [[10]]. The technology tools have found their place in their business operations and occupy essential shares of their present functions. Many entrepreneurs consider ICT means to represent a necessity, comfortable communication and work tool and some even describe their importance as "incorporates everything I need" [[11]].

For example, the email represents a conduit through which work and its related information are distributed [[12]] - one can hardly consider a company not using it. Databases and data warehouses [[13]]-[[15]], knowledge management systems [[16]][[21]], intranets [[22]], instant messaging [[23]], digital discussion platforms [[24]], Wikis [[25]] and other tailored tools support and/or enable executions of their business operations and emerge new opportunities of future business activities.

In late 80's, groupware became a tool for sharing ideas at distance [[26]]-[[27]]. In the beginning, it referred to "a piece of software with shared access to its data" and identified a computer-based system with social group processes [[28]]. Nevertheless, it represented an important move from an individual's computer usage to group's practices. On the other hand, team collaboration cannot be limited only to the exchange of needed data. The grouped individuals must also participate on their idea's design and development, on exploiting and sharing their knowledge, opinions and experience. In other words, it must be a functioning team where the tasks of individuals are interconnected and depending on each other as teams create resources and add to environments while groups manage and redistribute resources without stable interpersonal relations [[29]]. The concept of virtual teams has been developing in a step- 
wise manner towards these concepts. The groupware evolved into computer-based systems that support groups engaged in a common task and now provides a multifaceted interface to a shared environment [[30]]-[[31]] in real time enabling team creation and functioning in times when the pace of information exchange is becoming a significant need for every company. ICT enables fast sharing and quick distribution of information [[32]].

From that point of view, virtual teams have to be considered as an intertwined composition of individuals and their technology. Some researchers describes the level of team virtuality as "the extent to which team members use virtual tools to coordinate and execute team processes" [[33]]. Its level expresses the degree in which the team members combine their virtual presence with the exploitation of communication via technology. Not all teams must be $100 \%$ virtual to achieve impressive results. Frequently, the team members combine their real and virtual presence to balance their time restrictions and/or travel obstacles.

To highlight the importance of the mutual interconnections among geographically distant and virtually assembled team members and the technology tools enabling the existence of such a team, our paper is devoted to the analysis of the ICT means and their extensive fostering support of the establishment and functioning of a team in a virtual world. The reason is also that despite the continuous research in the field of virtual teams that is documented by provided references of this contribution, there are still gaps to be exploited that would enhance the theoretical comprehension of the conception of virtual collaboration and teaming [[35]]: the knowledge sharing has not reached the expected level.

Our paper is organized as follows: In Section 2, we specify the concept of a virtual team by reviewing its definition and providing our perception of the term, define its functions and identify advantages and benefits it provides to business organizations. In Section 3, we point to some drawbacks and difficulties of virtual teaming that may hinder achieving team objectives and disrupt mutual collaboration among team members. In Section 4, the Nonaka's and Takeuchi's SECI model [[37]]-[[39]] serves us as a benchmark for covering teams' activities and communication processes and for identifying software tools facilitating their execution. Our methodology covers collaboration tools in business organizations as well as those in academic institutes used for educational purposes. The collected information was then projected into the SECI model structure and discussed. In Conclusions, we summarize our key results, evaluate our approach, and assign its future development.

\section{$2 \quad$ Virtual Team}

In this section we identify the differences between locally-allocated teams and the virtual ones and compare them in order to define the concept of "virtual team".

Multinational companies have exploited international expert teams for years. In the past, their personal collaboration on an agreed site was their leading style of work. The global financial crisis imposed travel budget cuts that intensified the trend of going virtually in business operations [[9]]. At the same time, the advancement of ICT 
allowed information specialists to participate in IT projects at distance and made it their common practice. The concept quickly spread around various organizations due to outsourcing and globalization and led to ever increasing internationalization of companies [[40]] i.e. the hypercompetitive business environment have been the catalyst for a new form of working unite - virtual team [[41]]. Its existence designates an abstract requirement for a group of individuals that collectively possesses certain skills necessary for fulfilling a given task [[42]]. Often, the members of virtual teams never meet face-to-face. They rely on email, video and/or phone conferencing, and special network-based collaboration tools supporting their work [[43]]. The virtual team is an emerging phenomenon with significant implications to the way of working we have known so far [[44]].

Alike a local team, the virtual team must in the first place be a functioning body. In other words, it is "a collection of individuals who are interdependent in their tasks, share responsibility for outcomes, see themselves and are viewed by others as an intact social unit embedded in one or more social systems, and collectively manage their relationships across organizational boundaries" [[45]]. It is formed by a limited number of people with complementary skills who are committed to a common purpose, performance goals, and approach for which they consider themselves mutually accountable [[46]]. Teams, unlike groups, consist of people with a high degree of interdependence geared toward the achievement of a goal or the completion of a task $[[5]],[[47]]$.

The virtual team members interact through interdependent tasks targeted to a common purpose and collaborate through ICT tools in a virtual world [[48]]. The main characteristic of virtual teams is their strong dependence on technologymediated communication and limited face-to-face interaction during the completion of their tasks mostly caused by the geographical dispersion of their members [[49]] the members can span the World [[50]]. In extreme versions, team members speak different native languages, are situated on different continents in various countries, interact exclusively through computer mediated communication using a lingua franca that represent a foreign language (mostly English) for all of team members and rarely or never see or even speak to one another directly face-to-face in person [[51]]. Virtual teams allow managers to summon employees having no formal relation to each other or even do not know anything about each other prior their inclusion [[52]]. On one side, this allows selecting people with suitable skills and experience, on the other side; it might hinder their future communication as shown below. In principle, more than one group might have the required mix of skills and could play the role of concrete satisfier in a particular (virtually organized) task [[42]]. As the organizations have a limited amount on resources and try to use them wisely, the virtual teams open new opportunities for people from around the world. The virtual environment diminishes the importance of the place of living and origin - only the performance, skills and character of individuals become important. Furthermore, use of ICT for the execution of business operation and virtual teaming leads to cost reductions, increased operational efficiency and enhanced innovation due to the acquisition of highly skilled employee teams without geographical and time barriers [[53]]. 
In the academic world, several applications form virtual learning environments [[54]], e.g. the learning open source platform Moodle [[55]]-[[56]], BlackBoard [[57]], NovoEd [[58]], etc. interactive course materials, labs and quizzes [[59]]-[[60]] as well as tutorials and simulations [[61]]. Research findings show a higher stress on the development of ICT applications in order to make students more confident in their digital competences [[62]] expecting students to work in virtual teams is less frequent. At the same time, such projects enrich students with experience in a real world of intercultural communication, time zones, time management and virtual teaming [[63]] presuming that they are cautiously designed and the team members are appropriately instructed [[64]]. They provide an invaluable experience that can be later efficiently exploited by the students' future employers.

The review of above sources can be summarized as follows:

- Virtual collaboration through a computerized network allows companies to reallocate their resources in accordance to the needs of their business operations. Search for appropriate candidates is no longer bound to the given geographical location.

- Communicating and sharing information, data or knowledge is a team-formative component that often forces its members to leave their comfort zones and expectantly results in a synergy effect.

- The projects can benefit from higher creativity resulting from the team members' cultural and professional diversity. That may lead to significant innovations, increased performance and effort gains.

- Team's virtual collaboration should support perceiving co-workers through their expertise and consequently be less blurred by their personal sympathy, character or unfriendliness. Due to that, discrimination factors caused by prejudices or biases can be reduced.

- All team communication can be protocolled and analyzed, i.e., the effectiveness and efficiency of the problem solution can be studied and evaluated. The lessons learned can be exploited in the future.

We therefore define the virtual team as an organizational unit which existence indispensably depends on ICT. It is built through a group of people with complementary skills who are assigned with interdependent and inseparable tasks leading to a common goal achieved through their common endeavor to overcome geographical, cultural and social barriers.

Some characteristics can occasionally be softened. For example, the team members can sporadically meet with each other. In our interpretation of the concept, such encounters are rather exceptional and a prevailing majority of work and communication runs in the virtual space. The face-to-face encounters are especially recommended during initial stages of durable projects. Even in short-term projects, they usually lead to tighter relations among the team members. Similarly, a geographical distribution is not a must - virtual team can be built upon a local group applying teleworking. 


\section{Team Structure and its Impacts}

It is important to stress that practically all factors affecting local ("real") teams can influence virtual teams, too. Naturally, there are some specifics for them - both positive and negative.

\subsection{Geographical Dispersion}

As the distance between team members grows, the cultural diversity [[65]] becomes a significant determinant. It impacts the team members' behavior [[66]] but it may also increase their creativity leading to better alternatives of problem solutions [[67]]-[[69]]. Although the cultural diversity has a positive influence on decisionmaking, it has a negative influence on communication [[70]]. Cultural differences result in problems in cohesion formation [[71]], lead to misunderstandings and cause conflicts [[72]]-[[73]] as well as deprive mutual trust among team members [[74]]. Communication challenges based on cultural diversity may affect the teams' ability to engage in a constructive conflict [[75]] and may transmute it into a dysfunctional one. As a result, even though ICT allows connecting people across locations and enables their partnership, such collaboration is in general not as successful as the collaboration of individuals who are physically sharing the work environment [[76]].

In specific cases, the partner's identity plays a substantial role in the process, for example in virtual classrooms [[77]] or when a decision must be made by an authorized individual. The impossibility of his/her authentication may lead into ethical dilemmas or to impossibility to complete the executed process.

The lack of direct interaction amongst team members tends to disrupt social structures including social linkages, relationships and the sense of connectedness to others [[78]].

\subsection{ICT Infrastructure}

Another aspect that significantly influences the performance of virtual teams represents the technology itself and factors connected to it: the participant's technological proficiency [[79]], the used technical tool and/or its system incompatibility [[80]][[81]], technology failures [[75]], break downs [[82]] or outages [[83]]-[[85]]. The reliability of applied technology and its level of "user-friendliness" can lead to users" frustration, to a decrease of their performance, to stagnations and even to stopping of the solution process. The use of different or incompatible technology among individual team members can cause difficulties in task execution as well [[80]]-[[81]].

The utilization of ICT tools in organizations and their integration in business operations allowed also providing real time written group communication of people who may and does not have to be assembled in one room. In case of written group chats also among participants gathered at one place, the communication is silent and does not disturb other individuals present in the same room. This also provides the possibility of resource optimization in form of room reorganization (e.g. open offices). 
Furthermore, written communication offers the possibility of storing and archiving of discussed topics and returning to the topic at any time of need: repeated interaction/comprehension/learning.

\subsection{Style of Communication}

Problems with an insufficient broadband and slow data transfer are frequently solved by using asynchronous communication. When the distributed team relies on it, delays can appear [[86]]-[[87]]. This can postpone the completion of the task compared to the communication on synchronous base. Asynchronous and, in particular, written communication takes longer and may have a negative impact on team performance, namely, when not all team members are fully proficient in the language used as their lingua franca.

The selectivity and/or omission of some team members in distribution of a particular information (done by an accident or on purpose), leads to unnecessary misunderstandings, conflicts about workflow or frustration within the group. Discriminating information processing caused by its selective distribution (when some team members do not receive certain substantial information) often leads to inefficiency and may have disastrous consequences [[88]].

Certain omissions in information transfer and distribution are inherent to the virtual teams. The limitations are always present due to the fact that the technology is unable to transmit neither context nor emotions. The inability to transfer contextual information and its type and amount across time and distance represent a major consideration for virtual teams [[89]]. The contextual factors evoke significant differences between traditional team work and the virtual team work [[90]] and impact their overall outcomes and performance significantly because the contextual information is the key to effectiveness. In distributed teams, it is identified with difficulties. It may resolve into coordination problems [[91]]. Furthermore, research results confirmed a relation among team conflict, team performance and contextual information with conflict avoidance and team performance being contingent to contextual information [[92]].

Another factor impacting communication is the individualism and collectivism emphasis that is present in various cultures differently [[93]] and accounts for most of the variance in global differences [[94]]. Individualistic cultures value autonomy, seek self-actualization and therefore prefer working alone [[95]]. Individualist-oriented individuals are better at sharing explicit knowledge [[96]] and yields higher tendency for using ICT means like phone, e-mail and repositories for communication [[97]]. On the other hand, collectivist-oriented persons prefer to share tacit knowledge: collectivistic persons learn mainly through mutual exchange with peers and experts building on their experience [[98]]. They tend to communicate via ICT tools as phone, e-mail and instant messenger [[94]].

\subsection{Motivation and Leadership}

Compared to local teams having physically presented individuals, the collaboration in a virtual environment requires more intensive motivation of its team members and 
an extensive support by its team leader to maintain the same level of performance effectivity [[99]]-[[100]]. The members are likely missing their regular face-to-face interaction and therefore it needs to be intentionally created [[101]]. This adds extra load to skills of the team leader. Insufficient and ad-hoc motivation of workers and insufficient support of their collaboration can cause stagnation similar to a strategy loss.

\section{$4 \quad$ Virtual Collaboration and the SECI Model}

The collaboration of a virtual team has to lead to a real outcome. As we have seen, not all barriers to it are objective and rational. For this reason, team leaders have to concentrate on managing both rational and not-fully-rational factors. As [[102]] shows, the Nonaka's and Takeuchi's SECI model [[37]]-[[39]] can clarify the importance of not-fully-rational knowledge in the terms of learning processes and, in this way, facilitate the evolution of mutually shared knowledge within teams.

\subsection{Explicit and Tacit Knowledge}

Knowledge in organizations is generally classified into 2 types: explicit and tacit [[103]].

- Explicit knowledge represents the portion of our total knowledge we are aware of. As such, it is easier to codify it [[104]] and, subsequently, to digitize. In its digitized format it can be transmitted to others through ICT [[105]], i.e. it represents a natural, wide spread and generally accepted part of virtual team's collaborative activities.

- In difference to it, tacit knowledge represents highly personal and context-specific experiences, know-how and skills [[106]]. It is difficult to codify it, to explain it [[104]], to formalize it and to communicate it to the others [[107]]. On the other hand, it is always present as M. Polanyi explained in his famous quote: "We can know more than we can tell" [[108]].

The virtual teams must exchange, exploit and elaborate their both explicit knowledge (documents, data, processes, etc.) and tacit knowledge (reasoning, personal and/or personalized views, feelings, preferences and others) to carry out their tasks.

\subsection{Transferring Knowledge}

Data transferred between computers is always explicit because they are represented by (digitally encoded) symbols inscribed by human hands or instruments. The obtained data help to the receiver to resolve a question, to disclose or to reveal distinctions or to evoke a new action [[109]]. At the same time, data becomes information through its processing and interpretation [[110]] - by judgements made by an individual or a group. If the team collaboration would only require data exchange, there would be no problems. They appear when for example the receiver's judgement dif- 
fers from the original meaning encoded by the sender. The partners then act in accordance to their distinct interpretations. As their believed (but different) interpretations form preconditions for their knowledge [[111]] and become new knowledge through their individual cognitive effort [[112]], even the smallest deviations may result to dissimilar interpretations. As the processes are unconscious, none of the partners may be aware of his/her delusion. Due to the direct contact of the partners, disclosing it is usually easier in face-to-face environments than in virtual ones. For this reason, it is difficult to determine when data becomes (relevant) information and when this information becomes (relevant) knowledge [[113]].

Explicit knowledge is being transferred through both ICT and non-ICT methods [[114]]. It has been confirmed that data emerges only after there was initial information, and that information emerges only based on existing knowledge [[112]]. Unless these processes are not coordinated ("unified") within the collaborating group, the risk of misunderstanding is present even in the case of explicit knowledge transfer.

Tacit knowledge is primarily transferred by non-ICT methods. Research confirmed that its transfer can be facilitated through personalized communication tools as video and phone records and conferences [[115]]-[[117]] and by email [[117]] due to transmitting some of their human-oriented features as facial expressions or style of writing.

\subsection{The SECI Model}

Nonaka's and Takeuchi's SECI model [[37]]-[[39]] describes the process of knowledge conversion during which tacit and explicit knowledge expands in quality and quantity [[118]]. It compromises 4 processes known as Socialization; Externalization; Combination; and Internalization. It highlights the importance of tacit knowledge and proposes relevant human interventions in order to achieve the desired goal - well-balanced and properly distributed knowledge among the team members. It indicates what the team leaders and members have to keep in mind to ensure a fruitful interaction and to create a team out of a group with the respect to the (full or partial) absence of the face-to-face interaction.

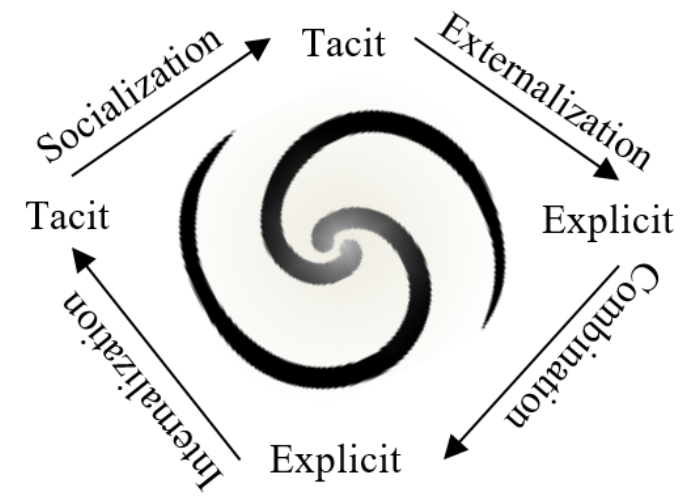

Fig. 1. SECI Model describing process of knowledge conversion 
Originally, software tools have been designed to automate a manual processes or to replace physical artifacts by more malleable and versatile virtual artifacts [[118]]. With the development of virtual teams, a pool of tools used by their members is growing. Our below categorization and descriptions are therefore incomplete. There are many valuable equivalents and alternatives to those mentioned below.

During Socialization, tacit knowledge is shared among individuals by converting it into new tacit knowledge [[118]]. This stage is utilized more by individuals from cultures with collectivistic emphasis [[96]] where persons prefer mutual exchange of experiences with colleagues, peers, experts and professionals as the main learning mode [[98]]. Still, in any team, there are moments when the problems must be "outspoken" and communicated face-to-face. Socialization primarily relies on synchronous communication. In virtual teams, it includes formal and informal talks on strategy, brainstorming, exchange of experience, etc. It can be accomplished by means of video conferences (e.g. Skype [[121]]) and their records, by live meetings [[122]] or even by desktop sharing often implemented in Instant Messaging (IM) clients [[23]][[94]] as well as by chatting through IM like (Lync [[119]] or Microsoft Communicator [[120]], Skype for Business [120]), internet-based messengers, virtual design tools [[123]] or digital discussion platforms [[24]]. Pair programming or a common execution of tasks are another viable options. During these activities, a mutual causal relationship is build emerging reciprocal trust. Trust leads to increasing interactions among team members including also informal relationship that will further strengthen reciprocated trust [[36]]. In all cases, interpersonal dialogues form the center of gravity during Socialization; the role of ICT (if exploited) is only supportive.

Some case studies showed that ICT tools foster the socialization phase in an immense manner through fast processing and provided visualization. Such rapid computation and illustration allow continuous increase of the number of artifacts a person/group can analyze. ICT enables exploration of new things and far more extended experimenting as was possible with paper before. ICT provides a platform for advancing knowledge through shared experiences [[124]]. As the same time it became far more difficult to express such experiences with words [[123]].

In the phase of Externalization, the gathered tacit knowledge is being codified into unambiguous concepts [[37]]-[[39]], [[115]], [[118]]. It denotes a conversion of tacit to a new explicit knowledge in a knowledge repository that serves as a resource for others [[123]]. This happens by putting down instructions, procedures, schemes, drawings, graphs, Gantt charts and others. Most used software tools for this are office bundles like typesetters (word editors), presentation and spreadsheet tools [[123]]. Wikis [[25]] and Intranet pages [[22]] also allow representing the organizational information in a "neutral way accepted by the community" which then serve as a benchmark for their previously presented tacit knowledge.

One example of externalization by ICT software tools can be automated creation of documentation in software development industry. Programmers provide only some standardized comments and description and then by starting some software tools (Java API Documentation generator [[125]], GhostDoc [[126]], and other documentation generating tools) generate web or pdf based manuals. Another spreading cutting tech- 
nology allows creating 3D models $-3 \mathrm{D}$ printing. Such new artefacts represent explicit knowledge through their unchanging and lasting existence.

Notice that asynchronous communication is usually sufficient for these processes. Still, the produced knowledge in its explicit format (a text, figures, tables, charts, etc.) has to be approved in advance and then accepted by all involved. It is recommended to consult their earlier version(s) to make certain that it will be identically interpreted by everyone. These consultations should preferably be done using synchronous means.

In the Combination stage, explicit knowledge is systematically processed and then converted into more sophisticated systems [[37]]-[[39]], [[115]], [[118]] and possibly elaborated by them. This phase is more autonomy-oriented and therefore more preferably utilized by individualistic persons [95] and uses mostly asynchronous communication ICT tools like repositories for collaboration among peers [[94]]. A variety of options starts with aggregating data extracted from databases, data warehouses [[128]] and repositories (SharePoint [[130]]) code repositories (e.g. Team Foundation Server (TFS) [[131]], SubVersion (SVN) [[132]], Git [[133]], Mercurial [[134]] etc.) creating new knowledge using Big Data techniques [[128]]. The new knowledge produced by its author (regardless whether a human and/or a software tool) is then presented in a (possibly different) explicit data format. Again, this portion of collaboration can be done in an asynchronous way. In exceptional cases, when all Combination-related processes are performed by computers, there is no need for synchronous communication.

Examples for the Combination phase fostered by ICT can be found everywhere: e.g. predefined layout and color settings of documents or webpages, picture collections, function bundles etc. Already during the interaction with software and ICT tools we use several artefacts provided by the software and combine it with our content, our added value. With the emergence of mobile ICT, smartphones in particular, people started to shoot and include also pictures in their conversation, instead of pure writing for taking notes or to exhaustively describe place, surroundings and feelings through visualization [[11]], [[129]].

A supportive motivation of team members for transparent collaboration and knowledge sharing may be based on individualistic principle: performance based incentives [[96]] as financial reward, promotion, professional development like educational opportunity or social recognition [[36]].

Another very important factor for Combination is trust: the perceived trustworthy of resources in repositories influence their exchange and combination [[135]]. The credibility of such repositories can be provided through the social recognition of contributors and also through ICT tools that may check statically its compliance with some predefined rules and best practices like a static code analysis in the case of programming, the indexation in scientific databases or the impact factor for a scientific knowledge base or checklists for processes etc.

Internalization denotes a process of embodying explicit knowledge into individualized tacit knowledge through a series of iterations [[37]]-[[39]], [[115]], [[118]]. As people need to comprehend newly obtained explicit data and think about them in their individual terms, this last step must always be present. The new knowledge is ab- 
sorbed as the person's "mental ownership" and becomes an integral part of his/her system of believes and values. As a result, it also becomes a part of his/her "intellectual weaponry" and can be used in the next steps as a basis for future development. The internalizations usually run through the interpretation of examples, making analogies, inclusion of the piece into the existing knowledge system etc. "Learning by doing" is also a method of internalization. In virtual teams, it may consist of making product's tests, of visualization of processes, of communicating them to their future users, of checking the programming code for compliance with teams' rules and coding practices (e.g. SonarQube [[136]]) and many others. This also includes necessary approvals by senior management through review process and accepting their recommendations (e.g. TFS [[131]]). A similar process is denoted by workflows [[115]] and process flows that usually represent a standard collection of tasks with particular order where the output of current step represents the input for subsequent step. Often, the newly developed processes must be incorporated into the company's standards. Multiple executions of set up workflow denote iterations and gaining experience, in other words "learning by doing at the company's level".

In case of using a 3D printer the internalization is enriched also by tactile perception that strengthens the introjection and incorporation of new knowledge. This is also present in virtual environment when utilizing visualizing tools, 3D models or simulations [[123]] where the individual internalizes the knowledge through sense of sight, auditory sense and mental comprehension.

Whilst personal comprehension of the Combination outcomes can be accomplished individually, Internalization embraces a hidden risk. The process should result in the same (or highly similar) tacit knowledge of all team members. Thus, a comparison of their individual considerations is necessary. This lead to their next Socialization - the loop has been closed and may start again at a higher level.

Despite all the fostering support provided by ICT tool in communication and automation of business processes, it is very important to positively motivate the team members of a virtual team to share the knowledge and to contribute to the accomplishment of organizational goals based on the individualistic or collectivistic tendency of particular team members, respectively their culture: The emphasis on interactions that are beneficial to their individual careers for individualists and on individual involvement in team helping to achieve team goals in workplace [[96]].

In addition to this, it is crucial to clarify if the working environment is in compliance with caring culture where individuals feel free to openly suggest new concepts and ideas and will receive constructive criticism without fear of reprisal [[137]]. Such an environment represents essential prerequisite of knowledge creation.

\section{Conclusions}

As the virtual teams develop new knowledge (in its very broad sense), the SECI model can serve to them as a metaphor. It covers the entire cycle of team's learning from an initial idea (as a rule, vague one), through its specification and elaboration to a final solution accepted by the entire team. 
During this process, both tacit and explicit knowledge must circulate among its members. Due to their dispersion, using various ICT support becomes a must. The collaboration tools that must be purchased, implemented, and maintained in their operational mode. At the same time, using incompatible (or badly compatible) tools may have undesired effects. The same holds for wrongly implemented tools and those not used to their full extent. These drawbacks can result into failures.

To minimize the risk, we classified the functions of virtual teams and their key knowledge transfer steps above. As the information in any digital environment must be appropriately encoded, it is explicit by definition. Its transformation to its tacit counterpart can only be achieved by its appropriate presentation, selection of communication channel, frequency of knowledge exchange, way of synchronization, individual and/or team couching and others. Briefly speaking, the success relies on a balanced solicitation of synchronous and asynchronous communication and on its quality. Their application must be coordinated by the leader who has to oversee both roles and behavior of the team members and to estimate the intensity of each form of communication during every stage. He/she has to especially control aggravating of undesired variances in their tacit knowledge and its fluctuation because they might lead to the deterioration of the team's mutual knowledge base.

Our proposed framework therefore can serve as a manual for building appropriate environments for virtual collaboration not only in their technical meaning but also as places for interpersonal communication. To achieve it, the importance of synchronous communication is underlined. It is critical during the Socialization and Internalization stages and highly important for controlling Externalization processes. Only the Combination can be (in special cases) completely left to computers. The team leaders have to bear in their minds that the selection of the most appropriate ICT tool for each and every stage of the SECI model and its application must reflect the importance of tacit knowledge.

\section{Acknowledgment}

This work was supported by the cooperation of the School of Management (Vysoká škola manažmentu) and the Faculty of Management, Comenius University in Bratislava. This paper is an output of the science project Visegrad Fund - No. 11610547 Support for e-business in V4 countries.

\section{$7 \quad$ References}

[1] Kumar, R. R., Stauvermann, P. J., Samitas, A. (2015). The effects of ICT* on output per worker: A study of the Chinese economy. Telecommunications Policy, 40(2-3): 102-115.

[2] Minhyung, K. (2010). The mobile big bang. SERI Quarterly, 3(4):p. 79. https://doi.org/10.1016/j.telpol.2015.06.004

[3] Riemer, K., Frößler, F., Klein, S. (2007). Real time communication-modes of use in distributed teams. $15^{\text {th }}$ European Conference on Information Systems (ECIS), June 7-9 2007, St Gallen, Switzerland, pp. 286-297. 
[4] Sarker, S., Sahay, S. (2002). Information systems development by US-Norwegian virtual teams: implications of time and space. $35^{\text {th }}$ Annual Hawaii International Conference on System sciences (HICSS), Big Island, Hawaii, January 7-10 2002, pp. 1-10. https://doi.org/10.1109/hicss.2002.993875

[5] Chen, F., Sager, J. Train to work effectively in virtual environments: a framework of virtual team competency. $13^{\text {th }}$ Americas Conference on Information Systems (AMCIS), December 2007, Keystone, Colorado, p. 104, pp. 1-11.

[6] Jorgenson, D. W., Vu, K. M. (2016). The ICT revolution, world economic growth, and policy issues. Telecommunications Policy, 40(5): 383-397. https://doi.org/10.1016/j.tel pol.2016.01.002

[7] Dávideková, M., Greguš ml., M. (2016). Software Application Logging: Aspects to Consider by Implementing Knowledge Management. $2^{\text {nd }}$ International Conference on Open and Big Data (OBD), August 22-24 2016, Vienna, Austria, pp. 102-107. https://doi.org/10.1109/OBD.2016.22

[8] Dávideková, M., Greguš ml., M. (2016). The Impact of Globalization on Team Composition: Virtual and Local Team. $16^{\text {th }}$ International Scientific Conference on Globalization and its Socio-Economic Consequences, University of Žilina, The Faculty of Operation and Economics of Transport and Communication, Department of Economics October 5-6 2016, Žilina, Slovakia, pp. 354-361.

[9] Klitmøller, A., Lauring, J. (2013). When global virtual teams share knowledge: media richness, cultural difference and language commonality. Journal of World Business, 48(3): 398-406. https://doi.org/10.1016/j.jwb.2012.07.023

[10] Ivanochko, I., Urikova, O., Greguš, M. (2014). Mobile technologies enabling collaborative services management. International Journal of Services, Economics and Management, 6(4): 310-326.

[11] Dávideková, M., Greguš ml., M. (2016). Case study of the use of means of information and communication technology for execution of daily business operations by entrepreneurs in Slovak republic," 18th International Scientific Conference on Economic and Social Development - "Building Resilient Society", December 9-10 2016, Zagreb, Croatia, pp. 98108.

[12] Whittaker, S., Bellotti, V., Gwizdka, J. (2006). Email in personal information management. Communications of the ACM, 49(1): 68-73. https://doi.org/10.1145/1107458.1107 $\underline{494}$

[13] Cios, K. J., Pedrycz, W., Swiniarski, R. W. (1988). Data mining and knowledge discovery. In Cios, K. J., Pedrycz, W., Swiniarski, R. W. (eds.) Data mining methods for knowledge discovery, 458: 1-26. New York: Springer.

[14] Strong, D. M., Lee, Y. W., Wang, R. Y. (1997). Data quality in context: a new study reveals businesses are defining data quality with the consumer in mind. Communications of the ACM, 40(5): 103-110. https://doi.org/10.1145/253769.253804

[15] Fayyad, U., Piatetsky-Shapiro, G., Smyth, P. (1996). From data mining to knowledge discovery in databases. AI Magazine, 17(3): 37-54.

[16] Alavi, M., Leidner, D. E. (1999). Knowledge management systems: issues, challenges, and benefits. Communications of the AIS, 1(2es): 1-37.

[17] Meso, P., Smith, R. (2000). A resource-based view of organizational knowledge management systems. Journal of Knowledge Management, 4(3): 224-234. https://doi.org/10.1108/ 13673270010350020

[18] Maier, R., Hädrich, T. (2011). Knowledge management systems. In Schwartz, D. G. (eds.) Encyclopedia of Knowledge Management: pp. 779-790. Hershey: Idea Group Inc. https://doi.org/10.4018/978-1-59904-931-1.ch076 
[19] Alavi, M., Leidner, D. E. (2001). Review: knowledge management and knowledge management systems: conceptual foundations and research issues. Management Information Systems Quarterly, 25(1): 107-136. https://doi.org/10.2307/3250961

[20] Huber, G. P. (2001). Transfer of knowledge in knowledge management systems: unexplored issues and suggested studies. European Journal of Information Systems, 10(2): 7279. https://doi.org/10.1057/palgrave.ejis.3000399

[21] Malhotra, Y. (2004). Why knowledge management systems fail: enablers and constraints of knowledge management in human enterprises. In Malhotra, Y. (eds.) Handbook on knowledge management, 1: pp. 577-599. Heidelberg: Springer. https://doi.org/10.1007/ 978-3-540-24746-3 30

[22] O'Leary, D. E. (1998). Guest editor's introduction: knowledge-management systems: converting and connecting. IEEE Intelligent Systems, 3:30-33. https://doi.org/10.1109/MIS.19 98.683179

[23] Ou, C. X. J., Davison, R. M. (2001). Interactive or interruptive? Instant messaging at work. Decision Support Systems, 52(1): 61-72. https://doi.org/10.1016/j.dss.2011.05.004

[24] Huysman, M., De Wit, D. (2004). Practices of managing knowledge sharing: towards a second wave of knowledge management. Knowledge and Process Management, 11(2): 8192. https://doi.org $/ 10.1002 / \mathrm{kpm} .192$

[25] Raman, M., Ryan, T., Olfman, L. (2005). Designing knowledge management systems for teaching and learning with wiki technology. Journal of Information Systems Education, 16(3): 311-320.

[26] Johansen, R. (1988). Groupware: computer support for business teams. New York: The Free Press.

[27] Johnson-Lenz, P., Johnson-Lenz, T. (1994). Groupware for a small planet. In Lloyd, P. (eds.) Groupware in the 21 st century: computer supported cooperative working toward the millennium: pp. 269-84. Westport: Greenwood Publishing Group Inc.

[28] Johnson-Lenz, P., Johnson-Lenz, T. (1982). Groupware: the process and impacts of design choices. In Kerr, E. B., Hiltz, S. R. (eds.) Computer-mediated communication systems: status and evaluation. Orlando: Academic Press.

[29] Fisher, S. G., Hunter, T. A. (1977). Team or group? Managers' perceptions of the differences. Journal of Managerial Psychology, 12(4): 232-242. https://doi.org/10.1108/026 83949710174838

[30] Ellis, C. A., Gibbs, S. J., Rein, G. (1991). Groupware: some issues and experiences. Communications of the ACM, 34(1): 39-58. https://doi.org/10.1145/99977.99987

[31] Greer, B. M., Luethge, D. J., Robinson, G. (2016). Utilizing virtual technology as a tool to enhance the workforce diversity learning. In Scott, C. L. Sims, J. D. (eds.) Developing workforce diversity programs, curriculum, and degrees in higher education AHEPD: pp. 258-279. Oklahoma: IGI Global. https://doi.org/10.4018/978-1-5225-0209-8.ch014

[32] Ogbomo, M. O., Ogbomo, E. F. (2008). Importance of information and communication technologies (ICTs) in making a heathy information society: a case study of Ethiope east local government area of delta state, Nigeria. Library Philosophy and Practice, p. 219: 1-8.

[33] Coleman, B. (2016). The Many Faces of a Virtual Team: A Review of Research Done on Individual Member Input to Virtual Teams. Honors Thesis. Greenville: East Carolina University.

[34] Bohumelová, M., Hvorecký, J. (2016). Museums and Galleries: From Traditional to Learning organizations. $14^{\text {th }}$ International Conference on Emerging eLearning Technologies and Applications (ICETA), 7 pp., in press. https://doi.org/10.1109/ICETA.2016.7802088

[35] Kirkman, B. L., Mathieu, J. E. (2005). The dimensions and antecedents of team virtuality. Journal of Management, 31(5): 700-718. https://doi.org/10.1177/0149206305279113 
[36] Hsu, M.-H., Ju, T. L., Yen, C.-H., Chang, C.-M. (2007). Knowledge sharing behavior in virtual communities: The relationship between trust, self-efficacy, and outcome expectations. International Journal of Human-Computer Studies, 65(2): 153-169. https://doi.org/10.1016/j.ijhcs.2006.09.003

[37] Nonaka, I., Konno, N. (1998). The concept of "ba": building a foundation for knowledge creation. California Management Review, 40(3): 40-54. https://doi.org/10.2307/41165942

[38] Nonaka, I., Toyama, R., Konno, N. (2000). SECI, ba and leadership: a unified model of dynamic knowledge creation. Long Range Planning, 33(1): 5-34. https://doi.org/10.1016/S0024-6301(99)00115-6

[39] Nonaka, I., Toyama, R. (2003). The knowledge-creating theory revisited: knowledge creation as a synthesizing process. Knowledge Management Research \& Practice, 1(1): 2-10. https://doi.org/10.1057/palgrave.kmrp.8500001

[40] Stawnicza, O. (2014). Information and communication technologies - creating oneness in globally distributed IT project teams. Procedia Technology, 16: 1057-1064. https://doi.org/10.1016/j.protcy.2014.10.060

[41] Potter, R. E., Balthazard, P. A. (2002). Virtual team interaction styles: assessment and effects. International Journal of Human-Computer Studies, 56(4): 423-443. https://doi.org/10.1006/ijhc.2002.1001

[42] Mowshowitz, A. (1997). Virtual organization. Communications of the ACM, 40(9): 30-37. https://doi.org/10.1145/260750.260759

[43] Jang, C. Y., Steinfield, C., Pfaff, B. (2000). Supporting awareness among virtual-teams in a web-based collaborative system: the team SCOPE system. ACM Siggroup Bulletin, 21(3): 28-34. https://doi.org/10.1145/605647.605652

[44] Jackson, P. J. (1999). Organizational change and virtual teams: strategic and operational integration. Information systems Journal, 9:313-332. https://doi.org/10.1046/j.13652575.1999.00066.x

[45] Hackman, J. R. (1987). The design of work teams. In Lorsch, J. W. (eds.) Handbook of organizational behavior: 315-342. New Jersey: Prentice Hall.

[46] Katzenbach, J. R., Smith, D. K. (2003). The wisdom of teams: creating the highperformance organization. Boston: Harvard Business School.

[47] Parker, G. M. (1994). Cross-functional teams. San Francisco: Jossey-Bass.

[48] Gunasekare, T. P. (2015). Virtual teams in Sri Lankan business process outsourcing companies. Journal of Business \& Economic Policy, 2(3): 155-160.

[49] Cohen, S. G., Gibson, C. B. (2003). Chapter 1, in the beginning: introduction and framework. In Cohen, S. G., Gibson, C. B. (eds.) Virtual teams that work: creating conditions for virtual team effectiveness: pp. 1-13. San Francisco: Jossey-Bass.

[50] Zaccaro, S. J., Ardison, S. D., Orvis, K. L. (2004). Leadership in virtual teams. In Day, D. V., Zaccaro, S. J., Halpin, S. M. (eds.) Leader development for transforming organizations: growing leaders for tomorrow: pp. 267-292. Mahwah: Lawrence Erlbaum.

[51] Bühlmann, B. (2006). Need to manage a virtual team?: theory and practice in a nutshell. Goettingen: Cuvillier Verlag.

[52] Hammer, M., Champy, J. (1993). Reengineering the corporation. New York: HarperCollins Publishers.

[53] Maruping, L. M., Magni, M. (2015). Motivating Employees to Explore Collaboration Technology in Team Contexts. Mis Quarterly, 39(1): 1-16.

[54] Kumar, S., Gankotiya, A. K., Dutta, K. (2011). A comparative study of moodle with other e-learning systems. IEEE $3^{\text {rd }}$ International Conference on Electronics Computer Technology (ICECT 2011), April 8-10 2011, Kanyakumari, India, vol. 5: pp. 414-418. https://doi.org/10.1109/icectech.2011.5942032 
[55] Selwyn, N. (2007). The use of computer technology in university teaching and learning: a critical perspective. Journal of Computer Assisted Learning, 23(2): 83-94. https://doi.org/10.1111/j.1365-2729.2006.00204.x

[56] Moodle. About Moodle [online] last modified on 12 February 2016, at 16:05. Available online: https://docs.moodle.org/31/en/ About_Moodle [cited 2016-05-30].

[57] Blackboard Inc. About Blackboard: At Blackboard, we're shaping the future of education with big ideas that are transforming the face of education [online]. Available online: http://emea. blackboard.com/about-us/index.aspx [cited 2016-05-30].

[58] NovoEd. Transform Learning: The online platform for the modern learner [online]. Available online: https://www.novoed.com/ [cited 2016-12-09].

[59] Edmunds, R., Thorpe, M., Conole, G. (2012). Student attitudes towards and use of ICT in course study, work and social activity: a technology acceptance model approach. British Journal of Educational Technology, 43(1): 71-84. https://doi.org/10.1111/j.14678535.2010.01142.x

[60] Balco, P., Greguš, M. (2014). The Implementation of Innovative Services in Education by Using Cloud Infrastructure and their Economic Aspects. Global Journal of Flexible Systems Management, 15 (1): 69-76. https://doi.org/10.1007/s40171-014-0060-2

[61] Goktas, Y., Yildirim, S., Yildirim, Z. (2009). Main barriers and possible enablers of ICTs integration into pre-service teacher education programs. Educational Technology \& Society, 12(1): 193-204.

[62] Wastiau, P., Blamire, R., Kearney, C., Quittre, V., Van de Gaer, E., Monseur, C. (2013). The use of ICT in education: a survey of schools in Europe. European Journal of Education, 48(1): 11-27. https://doi.org/10.1111/ejed.12020

[63] Long, S., Carlo, H., Fraser, J., Gosavi, A., Grasman, S. (2010). Building communication skills in supply chain management and facility logistics curriculum through multiinstitutional virtual teaming. American Society for Engineering Education, p. 436: 1-9.

[64] Hvorecký, J. (2006). Team projects over the internet. International Conference on Interactive Collaborative Learning (ICL), September 27-29 2006, Villach, Austria, pp. 1-5.

[65] Staples, D. S., Zhao, L. (2006). The effects of cultural diversity in virtual teams versus face-to-face teams. Group Decision and Negotiation, 15(4): 389-406. https://doi.org/10.1007/s10726-006-9042-x

[66] McDonough, E. F., Kahnb, K. B., Barczaka, G. (2001). An investigation of the use of global, virtual, and collocated new product development teams. Journal of product innovation management, 18(2): 110-120. https://doi.org/10.1016/S0737-6782(00)00073-4

[67] Ling, S. C. (1990). The effects of group cultural composition and cultural attitudes on performance. Digitized Theses, p.1870.

[68] McLeod, P. L., Lobel, S. A. (1992). The effects of ethnic diversity on idea generation in small groups. Academy of Management Proceeding, 1992(1): 227-231.

[69] McDonough, E. F., Kahn, K. B., Griffin, A. (1999). Managing communication in global product development teams. IEEE Transactions on Engineering Management, 46(4): pp. 375-386. https://doi.org/10.1109/17.797960

[70] Shachaf, P. (2008). Cultural diversity and information and communication technology impacts on global virtual teams: an exploratory study. Information \& Management, 45(2): pp. 131-142. https://doi.org/10.1016/j.im.2007.12.003

[71] Watson, W. E., Kumar, K., Michaelsen, L. K. (1993). Cultural diversity's impact on interaction process and performance: comparing homogeneous and diverse task groups. Academy of Management Journal, 36(3): 590-602. https://doi.org/10.2307/256593 
[72] Hertel, G., Geister, S., Konradt, U. (2005). Managing virtual teams: a review of current empirical research. Human Resource Management Review, 15(1): 69-95. https://doi.org/10.1016/j.hrmr.2005.01.002

[73] Kirchmeyer, C., Cohen, A. (1992). Multicultural groups their performance and reactions with constructive conflict. Group \& Organization Management, 17(2): 153-170. https://doi.org/10.1177/1059601192172004

[74] Maznevski, M. L., Chudoba, K. M. (2000). Bridging space over time: global virtual team dynamics and effectiveness. Organization Science, 11(5): 473-492. https://doi.org/10.1287/orsc.11.5.473.15200

[75] Ransone, C. L. (2014). The nature and influence of relationship on success in a virtual work environment. Doctoral dissertation, Antioch University.

[76] RE. Kraut, SR. Fussell, SE. Brennan, and J. Siegel, "Understanding effects of proximity on collaboration: implications for technologies to support remote collaborative work," Distributed Work, P. Hinds, and S. Kiesler, Eds. London: MIT Press, 2002, pp. 137-162.

[77] Bušíková, A., Melicheríková, Z. (2013). Ethics in e-learning. IADIS International Conference on e-Learning, Jul 2013, pp. 435-438.

[78] Santillan, C., Horwitz, S. K. (2016). Application of Collaboration Technology to Manage Diversity in Global Virtual Teams: The ThinkLet-Based CE Approach. Handbook of Research on Race, Gender, and the Fight for Equality, pp. 240-266. https://doi.org/10.4018/978-1-5225-0047-6.ch011

[79] Dubé, L., Paré, G. (2004). The multifaceted nature of virtual teams. In Pauleen, D. J. (eds.) Virtual teams: projects, protocols and processes: pp. 1-33, Hershey: Idea Group Publishing. https://doi.org/10.4018/978-1-59140-166-7.ch001

[80] Denhere, N., Hörne, T., Van der Poll, J. A. (2015). Managing globally distributed software development projects using virtual teams: a Middle East case study. Proceeding of the ACM Annual Research Conference on South African Institute of Computer Scientists and Information Technologists, p. 12, pp. 1-10. https://doi.org/10.1145/2815782.2815786

[81] Dossick, C. S., Homayouni, H., Lee, G. (2015). Learning in global teams: BIM planning and coordination. International Journal of Automation and Smart Technology, 5(3): 119135. https://doi.org/10.5875/ausmt.v5i3.916

[82] Daim, T. U., Ha, A., Reutiman, S., Hughes, B., Pathak, U., Bynum, W., Bhatla, A. (2012). Exploring the communication breakdown in global virtual teams. International Journal of Project Management, 30(2): 199-212. https://doi.org/10.1016/j.ijproman.2011.06.004

[83] Hinds, P. J., Weisband, S. P. (2003). Knowledge sharing and shared understanding in virtual teams. In Cohen, S. G., Gibson, C. B. (eds.) Virtual teams that work: creating conditions for virtual team effectiveness: pp: 21-36. San Francisco: Jossey-Bass.

[84] Riopelle, K., Gluesing, J. C., Alcordo, T. C., Baba, M. L., Britt, D., McKether, W., Monplaisir, L., Ratner, H. H., Wagne, K. H. (2003). Context, task, and the evolution of technology use in global virtual teams. In Cohen, S. G., Gibson, C. B. (eds.) Virtual teams that work: creating conditions for virtual team effectiveness: pp. 239-264. San Francisco: Jossey-Bass.

[85] Johnston, K. A., Rosin, K. (2011). Global virtual teams: how to manage them. IEEE International Conference on Computer and Management (CAMAN), May 19-21 2011, Wuhan, China, pp. 1-4. https://doi.org/10.1109/CAMAN.2011.5778849

[86] Bass, J. M., McDermott, R., Lalchandani, T. J. (2015). Virtual teams and employability in global software engineering education. $10^{\text {th }}$ IEEE International Conference on Global Software Engineering (ICGSE), July 13-16 2015, Ciudad Real, Spain, pp. 115-124. https://doi.org/10.1109/ICGSE.2015.21 
[87] Moe, N. B., Cruzes, D., Dyba, T., Mikkelsen, E. (2015). Continuous software testing in a globally distributed project," $10^{\text {th }}$ IEEE International Conference on Global Software Engineering (ICGSE), July 13-16 2015, Ciudad Real, Spain, pp. 130-134. https://doi.org/10.1109/icgse.2015.24

[88] Curseu, P. L., Schalk, R., Wessel, I. (2008). How do virtual teams process information? A literature review and implications for management. Journal of Managerial Psychology, 23(6): 628-652. https://doi.org/10.1108/02683940810894729

[89] Ratcheva, V., Vyakarnam, S. (2001). Knowledge management and business model innovation: building virtual relationships. In Malhotra. Y. (eds.) Distributed organizational environment: pp. 166-182. London: Idea Group Publishing.

[90] Coronas, T. T., Oliva, M. A., Luna, J. C. Y., Palma, A. M. L. (2015). Virtual teams in higher education: a review of factors affecting creative performance. International Joint Conference on Advances in Intelligent Systems and Computing, Springer, 369: 629-637. https://doi.org/10.1007/978-3-319-19713-5 55

[91] Fuller, R. M., Harding, M. (2015). The impact of interaction anticipation and incentive type on shared leadership and performance in virtual teams. $48^{\text {th }}$ IEEE Hawaii International Conference on System Sciences (HICSS), Big Island, Hawaii, pp. 732-741. https://doi.org/10.1109/hicss.2015.93

[92] Zhan, L., Wang, N., Shen, X.-L., Sun, Y. (2015). Knowledge quality of collaborative editing in Wikipedia: an integrative perspective of social capital and team conflict. $19^{\text {th }}$ AIS Pacific Asia Conference on Information Systems (PACIS 2015), p. 245, pp. 1-10.

[93] Orji, R. (2016). Persuasion and Culture: Individualism-Collectivism and Susceptibility to Influence Strategies. International Workshop on Personalization in Persuasive Technology (PPT'16), 1581, Salzburg, pp. 30-39.

[94] Triandis, H. C. (2001). Individualism-collectivism and personality. Journal of Personality, 69(6): 907-924. https://doi.org/10.1111/1467-6494.696169

[95] Sutton, J. L., Pierce, L. G., Burke, C. S., Salas, E. (2006). Cultural adaptability. In Burke, C. S., Pierce, L. G., Salas, E. (eds.) Understanding Adaptability: A Prerequisite for Effective Performance within Complex Environments, Advances in Human Performance and Cognitive Engineering Research, 6: pp. 143-173. Emerald Group Publishing Limited. https://doi.org/10.1016/s1479-3601(05)06005-4

[96] Chen, P., Cheung, Y., Lee, V. C. S., Hart, A. (2016). Knowledge Sharing via Informal Communities in a Globally Distributed Organization. International Symposium on Knowledge and Systems Sciences, pp. 30-43. Springer Singapore. https://doi.org/10.1007/ 978-981-10-2857-1 3

[97] Lee, C. S., Kelkar, R. S. (2013). ICT and knowledge management: perspectives from the SECI model. Electronic Library, 31(2): 226-243. https://doi.org/10.1108/02640 471311312401

[98] Letaifa, S. B., Goglio-Primard, K. (2016). How does institutional context shape entrepreneurship conceptualizations? Journal of Business Research, 69(11): 5128-5134. https://doi.org/10.1016/j.jbusres.2016.04.092

[99] Malhotra, A., Majchrzak, A., Rosen, B. (2007). Leading virtual teams. Academy of Management Perspectives, 21(1): 60-70. https://doi.org/10.5465/AMP.2007.24286164

[100] Carter, D. R., Seely, P. W., Dagosta, J., DeChurch, L. A., Zaccaro, S. J. (2015). Leadership for global virtual teams: facilitating teamwork processes. In Wildman, J. L., Griffith, R. L. (eds.) Leading global teams: pp. 225-252. New York: Springer. https://doi.org/10.1007/ 978-1-4939-2050-1 10

[101] Chase, N. (1999). Learning to lead a virtual team. Quality, 38(9): 76. 
[102] Hvorecký, J., Šimúth, J., Lichardus, B. (2013). Managing rational and not-fully-rational knowledge. Acta Polytechnica Hungarica, 10(2): 121-132.

[103] Lin, D., Liang, Q., Xu, Z., Li, R., Xie, W. (2008). Does knowledge management matter for information technology applications in China? Asia Pacific J of Management, 25(3): 489507. https://doi.org/10.1007/s10490-008-9087-2

[104] Levin, D. Z., Cross, R. (2004). The strength of weak ties you can trust: the mediating role of trust in effective knowledge transfer. Management Science, 50(11): 1477-1490. https://doi.org/10.1287/mnsc. 1030.0136

[105] Johannessen, J.-A., Olaisen, J., Olsen, B. (2001). Mismanagement of tacit knowledge: the importance of tacit knowledge, the danger of information technology, and what to do about It. International Journal of Information Management, 21(1): 3-20. https://doi.org/10.1016/ $\underline{\mathrm{S} 0268-4012(00) 00047-5}$

[106] Foray, D., Lundvall, B. (1998). The knowledge-based economy: from the economics of knowledge to the learning economy. In Neef, D., Siesfeld, G. A., Cefola, J. (eds.) The economic impact of knowledge: 115-121. Woburn: Butterworth-Heinemann. https://doi.org/10.1016/b978-0-7506-7009-8.50011-2

[107] Woo, J.-H., Clayton, M. J., Johnson, R. E., Flores, B. E., Ellis, C. (2004). Dynamic knowledge map: reusing experts' tacit knowledge in the AEC industry. Automation in Construction, 13(2): 203-207. https://doi.org/10.1016/j.autcon.2003.09.003

[108] Polanyi, M. (1997). The tacit dimension. In Prusak, L. (eds.) Knowledge in organizations: pp. 135-146. Woburn: Butterworth-Heinemann. https://doi.org/10.1016/B978-0-75069718-7.50010-X

[109] Green, A., Stankosky, M. (2010). In search of knowledge management: pursuing primary principles. Bingley: Emerald Group Publishing Limited.

[110] Spiegler, I. (2000). Knowledge management: a new idea or a recycled concept. Communications of the AIS, 3(4es): p. 2.

[111] Vance, D. (1997). Information, knowledge and wisdom: the epistemic hierarchy and computer-based information systems. American Conference on Information Systems (AMCIS), 1997: p.165

[112] Tuomi, I. (1999). Data is more than knowledge: implications of the reversed knowledge hierarchy for knowledge management and organizational memory. $32^{\text {nd }}$ IEEE Annual Hawaii International Conference on Systems Sciences (HICSS), Big Island, Hawaii, January 1999. https://doi.org/10.1109/hicss.1999.772795

[113] Davenport, T. H., Marchand, D. (1999). Is KM just good information management? Data, information and knowledge are points along a continuum. The financial times mastering series: mastering information management, pp. 2-3.

[114] Nguyen, T., Burgess, S. (2014). A case analysis of ICT for knowledge transfer in small businesses in Vietnam. International Journal of Information Management, 34: 416-421. https://doi.org/10.1016/j.ijinfomgt.2014.02.009

[115] Nonaka, I., Von Krogh, G. (2009). Perspective-tacit knowledge and knowledge conversion: controversy and advancement in organizational knowledge creation theory. Organization Science, 20(3): 635-652. https://doi.org/10.1287/orsc.1080.0412

[116] Linde, C. (2001). Narrative and social tacit knowledge. Journal of Knowledge Management, 5(2): 160-171. https://doi.org/10.1108/13673270110393202

[117] Smith, E. A. (2001). The role of tacit and explicit knowledge in the workplace. Journal of Knowledge Management, 5(4): 311-321. https://doi.org/10.1108/13673270110411733

[118] Lopez-Nicolas, C., Soto-Acosta, P. (2010). Analyzing ICT adoption and use effects on knowledge creation: an empirical investigation in SMEs. International Journal of Information Management, 30(6): 521-528. https://doi.org/10.1016/j.ijinfomgt.2010.03.004 
[119] Lync [online]. Available online: https://www.microsoft.com/en-us/store/p/lync/9wzdn crfhvhm [cited 2016-12-09].

[120] Microsoft Office Communicator [online]. Available online: https://www.microsoft.com/ en-us/download/details.aspx?id=10176 [cited 2016-12-09].

[121] Skype [online]. Available online: https://www.skype.com/en/ [cited 2016-06-05]

[122] Microsoft Office Live Meeting 2007 [online]. Available online: https://www318.live meeting.com/cc/usda/join [cited 2016-06-05]

[123] Vaccaro, A., Veloso, F., Brusoni, S. (2009). The impact of virtual technologies on knowledge-based processes: An empirical study. Research Policy, 38(8): 1278-1287. https://doi.org/10.1016/j.respol.2009.06.012

[124] Peltokorpi, V., Nonaka, I., Kodama, M. (2007). NTT DoCoMo's launch of I-mode in the Japanese mobile phone market: a knowledge creation perpective. Journal of Management Studies, 44(1): 50-72. https://doi.org/10.1111/j.1467-6486.2007.00664.x

[125] Oracle: javadoc - The Java API Documentation Generator [online]. Available in: http://docs.oracle.com/javase/7/docs/technotes/tools/windows/javadoc.html [cited 201612-08]

[126] SubMain: GhostDoc: Painless Help Documentation [online]. Available in: http://submain.com/products/ghostdoc.aspx [cited 2016-12-08]

[127] Nonaka, I., Takeuchi, H. (1995). The Knowledge Creating Company. New York: Oxford University Press.

[128] Chou, T. C., Chang, P. L., Tsai, T. C., Cheng, Y. P. (2005). Internal learning climate, knowledge management process and perceived knowledge management satisfaction. Journal of Information Science, 31(4): 283-296. https://doi.org/10.1177/0165551505054171

[129] Dávideková, M. (2016). Digitalization of Society: Smartphone - a Thread? $8^{\text {th }}$ International Research Conference Management Challenges in the $21^{\text {st }}$ Century: Digitalization of the Society, Economy and Market: Current Issues and Challenges, April 12, Bratislava, Slovakia: pp. 314-320. Bratislava: Vysoká škola Manažmentu v Trenčíne.

[130] SharePoint: Empowering teamwork [online]. Available online: https://products.office. com/en-us/sharepoint/collaboration [cited 2016-06-05]

[131] Team Foundation Server: An enterprise-grade server for teams to share code, track work, and ship software [online]. Available online: https://www.visualstudio.com/enus/products/tfs-overview-vs.aspx [cited 2016-06-05]

[132] Apache ${ }^{\mathrm{TM}}$ Subversion ${ }^{\circledR}$ : Enterprise-class centralized version control for the masses [online]. Available online: https://subversion.apache.org/ [cited 2016-06-05]

[133] Git: a free and open source distributed version control system designed to handle everything from small to very large projects with speed and efficiency. [online]. Available online: https://git-scm.com/ [cited 2016-06-05]

[134] Mercurial: a free, distributed source control management tool [online]. Available online: https://www.mercurial-scm.org/ [cited 2016-06-05]

[135] Tsai, W., Ghoshal, S. (1998). Social capital and value creation: the role of intrafirm networks. Academy of Management Journal, 41(4): 464-476. https://doi.org/10.2307/257085

[136] SonarQube: open platform to manage code quality [online]. Available online: http://www.sonarqube.org/ [cited 2016-06-05]

[137] Young, J. (2012). Personal Knowledge Capital: The inner and outer path of knowledge creation in a web world. Oxford: Chandos Punblishing. https://doi.org/10.1533/ $\underline{9781780633664}$ 


\section{Authors}

Monika Dávideková is a Researcher of the Faculty of Management, Comenius University in Bratislava, Slovakia. She received her Master and PhD in Telecommunication at Slovak University of Technology in 2011 and 2016, respectively, and Master in Management in 2015 at Comenius University, all in Bratislava, Slovakia. Her research areas in Telecommunications are Coding Theory, Signal Processing and in Management she focuses on Virtual Teaming, Knowledge Management and Utilization of ICT in Business Management.

Jozef Hvorecký is a professor and Vice Dean at Vysoká škola manažmentu in Bratislava, Slovakia and Honorary Lecturer of the University of Liverpool. He has got $\mathrm{PhD}$. in Computer Programming at the Academy of Sciences of the USSR in Moscow. His research areas are Computer Education, Knowledge Management, and University Management.

Article submitted 13 December 2016. Published as resubmitted by the authors 07 February 2017. 